九州大学学術情報リポジトリ

Kyushu University Institutional Repository

\title{
Identification of Symbiotic Arbuscular Mycorrhizal Fungi in Korean Ginseng Roots by 18S rDNA Sequence
}

Cho, Nam-Seok

School of Forest Resource and Rural Engineering, Chungbuk National University

Kim, Dong-Hum

School of Forest Resource and Rural Engineering, Chungbuk National University

Cho, Hee-Yeon

Keck School of Medicine, University of Southern California

Shin, Yoo-Soo

National Institute of Crop Science, RDA

他

https://doi.org/10.5109/9313

出版情報：九州大学大学院農学研究院紀要. 52 (2)，pp.265-274，2007-10-29. Faculty of Agriculture, Kyushu University

バージョン :

権利関係 : 


\title{
Identification of Symbiotic Arbuscular Mycorrhizal Fungi in Korean Ginseng Roots by 18S rDNA Sequence
}

\author{
Nam Seok-CHO ${ }^{1}$, Dong-Hun KIM ${ }^{1}$, Hee-Yeon $\mathrm{CHO}^{2}$, Yoo-Soo SHIN ${ }^{3}$, \\ Young-Chang $\mathrm{KIM}^{3}$ and Shoji OHGA*
}

\author{
Laboratory of Forest Resources Management, Division of Forest Ecosphere Management, \\ Department of Forest and Forest Products Sciences, Kyushu University, \\ Sasaguri, Fukuoka 811-2415, Japan \\ (Received May 15, 2007 and accepted July 17, 2007)
}

\begin{abstract}
This study was carried out to perform the identification of arbuscular mycorrhizal fungi colonized in Korean Ginseng roots. Samples were soils and roots from various Ginseng cultivation sites of Chungcheong province in Korea. Those approaches include thorough investigation of morphological characteristics of spores harvested from Ginseng root associated soil and molecular biological identification of AM fungi in Ginseng roots. Based on the morphology of spores isolated from the soils, five distinguishable spore morpho-types AM fungi were found; Glomus mosseae, Glomus intraradices, Gigaspora margarita, Acaulospora longular and Gigaspora gigantea. Among these, Glomus mosseae, Glomus intraradices and Acaulospora longular were the most commonly encountered species. Glomus and Acaulospora were dominant with frequencies of $55 \%$ and $25 \%$, respectively.

AM fungi colonization rates were progressed with the increase of cultivation period, relatively low infection rate in two year-old root, heavily infected in three year-old root, cube shape of intensive hyphal coil and distributed toward longitudinally in four year-old root, and eventually clear internal arbuscular hypae and vescicle were observed in the five year-old roots.

By sequence analysis of the small subunit of the nuclear ribosomal DNA (18S rDNA), it was disclosed that Ginseng roots were associated with AM fungi as follows; 4 Glomus and 1 Acaulospora genera, Glomus sinuosum (AJ133706), Glomus fasciculatum (Y17640), Glomus intraradices (AY635831), Glomus mossae (AJ699064) and Acaulospora spp. (AY394664). There were observed only one AM fungus, Glomus sinuosum, in one year-old Ginseng root, but three AM fungi, Glomus fasciculatum, Glomus intraradices and Glomus sinuosum in two year-old root. Three year-old root was associated with two AM fungi, Glomus sinuosum and one new AM fungus, Acaulospora spp. (AY394664). There were found three AM fungi, Glomus sinuosum, Glomus fasciculatum and Glomus intraradices, in five year-old root.
\end{abstract}

\section{INTRODUCTION}

Arbuscular mycorrhizal (AM) fungi are ubiquitous in terrestrial ecosystem, forming symbiotic association with roots from the majority of plant species (Smith and Read, 1997a). In exchange for carbon from plant hosts, these fungi can facilitate plant uptake and transport of less mobile soil nutrients (such as phosphorus) (Bolan, 1991; Thingstrup et al., 2000; Jakobsen et al., 2001), enhance drought tolerance (Davies et al., 1993; Ruiz-Lozano et al., 2001; Kaya et al., 2003) and reduce pathogenic infections (Newsham et al., 1995; Abdalla and Abdel-Fattah, 2000). Although mycorrhizal fungi are traditionally believed to be non-host specific in their ability to infect plants, the benefit to each partner in any given interaction between AM fungus and host plant may depend on the particular species involved (Burrows and Pfleger, 2002a; Johnson et al., 2004).

It has been well documented that plant species is

${ }^{1}$ School of Forest Resources and Rural Engineering, Chungbuk National University, Cheongju 361-763, Korea

${ }^{2}$ Molecular Microbiology and Immunology, Keck School of Medicine, University of Southern California, Los Angeles, CA 90089, USA

${ }^{3}$ National Institute of Crop Science, RDA, Suwon, 441-857, Korea

* Corresponding author (E-mail: ohga@forest.kyushu-u. ac.jp) important as far as impacting individual fungal species or fungal assemblages (Bever et al., 1996; Eom et al., 1994; Eom et al., 2000; Lovelock et al., 2003). Since the root exudates of various plant species may affect the growth and colonization of specific mycorrhizal fungal species differently (Douds et al., 1996; Vierheilig et al., 1998), the co-existence of more than one plant species might alter mycorrhizal fungal growth, infection activity, spore production and species composition. Since higher plant diversity also likely enhances plant biomass (Tilman et al., 1996; Hector et al., 1999) resulting in a higher density of root material in the soil, coexistence of diverse plant species may better support mycorrhizal fungal growth and increase spore production. Mycorrhizal fungal species or fungal species assemblages have been shown to play an important role in the formation and maintenance of plant diversity and plant community structure (van der Heijden et al., 1998a, van der Heijden et al., 1998b and van der Heijden et al., 2003; Smith et al., 1999; Klironomos et al., 2000; O'Connor et $a l ., 2002$; Urcelay and Diaz, 2003). However, only a few studies have focused on whether and how plant coexistence or plant diversity influences the activities and species diversity of mycorrhizal fungi (Burrows and Pfleger, 2002a; Burrows and Pfleger, 2002b; Johnson et al., 2004). Burrows and Pfleger (2002a) reported that 30-150\% more spores were found in the plots with 16 
coexisting plants than in the corresponding plots consisting of only a single species. Sporulation of mycorrhizal species with large spores also increased significantly with increasing plant species, while sporulation of smaller-spored species varied in response to host diversity. Despite this evidence, it is not clear how coexisting plant species affect the growth and functions of mycorrhizal fungi.

Ginseng (Panax ginseng C.A. Meyer) has been cultivated for long period in Korea as one of the very important folks medicines. One major problem is root diseases encountered during long cultivation period. It was known that damping-off disease of Korean Ginseng is caused by mainly Fusarium sp., Rhizoctonia solani, and Pythium sp., root rots by Cylindrocarpon destructans, and root blight by Phytophthora cactorum (Oh et al., 1978; Yu et al., 1984; Darmon et al., 1991; Li. 1994; Shin et al., 1986). Consecutive planting of Ginseng in the same field may bring in serious root diseases and root-rot caused by Fusarium sp. (Li. 1994; Shin et al., 1986). Therefore Ginseng farmers have been paid their special attention to bed soil to avoid the introduction of any pathogens by means of completely exchanging top soil of the bed with new soil or sterilizing or fumigating the soil to kill any pathogens in the bed.

In recent years, mycorrhizae have been applied to environmental friendly agiculture to decrease the use of fertilizer and pesticide. It has been known that mycorrhizae may result in enhanced survival, nutrient acquisition, reproduction and growth for the component organisms (Smith and Read, 1997b; Molina, 1997: Lugo and Cabello, 2002). Ginseng is normally grown for 4 to 6 years in the same bed. Therefore in Ginseng cultivation, too much usuage of pesticide and fertilizer is strongly discouraged because of their slow degradation, possible accumulation in the soil and direct using Ginseng root by the people. Fortunately some researchers have been involved in mycorrhizal study related to Ginseng cultivation (Park et al., 1990; Han et al., 1996; Whitbread et al., 1996; McGonigle et al., 1999; Armstrong and Peterson, 2002; Woo et al., 2002; Lee et al., 2004; Auh, 2004). Lately Lee et al. (2004) precisely studied on the morphology of AM fungi infection in the ginseng roots related to the root age and soil texture. However, there are no enough informations on what kinds of mycorrhizal fungi exist in Ginseng roots, and how much affect those mycorrhizal fungi to the Ginseng growth because of very difficult identification of endomycorrhizal fungi not only in soil beds but also in roots.

Identification of biological species in the AM fungi was mostly investigated based on the morphological and developmental characteristics of fungal spores (Morton and Benny, 1990). More than 150 AMF species are described based on their spore morphology (Walker and Trappe, 1993), but spore morphotyping requires considerable experience (Clapp et al., 2001; Clapp et al., 2002) and spore counts may not reflect the in planta composition of AMF communities (Clapp et al., 1995; Merryweather and Fitter, 1998; Turnau et al., 2001), due to taxon-specific differences between sporulation and root colonization rates. Therefore, more adequate methods are needed to accurately identify the mycorrhizal fungi. The methodological advance in the study of mycorrhiza identification has been the application of PCR (Mullis and Falloona, 1987; Gardes et al., 1991; Henrion et al., 1992; Lanfranco et al., 1998). PCR-based molecular markers allowing differentiation between species or genotypes have become rapidly indispensable for ecological survey of the diversity of fungi (Lanfranco et al., 1998). The methodological advance in the study of mycorrhiza identification has been the application of PCR (Mullis and Falloona, 1987; Gardes et al., 1991; Henrion et al., 1992; Lanfranco et al., 1998). PCR-based molecular markers allowing differentiation between species or genotypes have become rapidly indispensable for ecological survey of the diversity of fungi (Lanfranco et al., 1998).

Progress in analyzing AMF diversity at species level in planta has recently been made by sequence analysis of the small subunit of the nuclear ribosomal DNA (18S rDNA) (Simon et al., 1992; Sanders et al., 1995; Helgason et al., 1998; Helgason et al., 1999, Kuhn et al., 2001; Vandenkoornhuyse et al., 2002). The rDNA has considerable utility to identify distantly related species or groups of related mycorrhizal fungi, and rDNA sequence data are accumulating very fast (Boscot et al., 2000). Thus, interspecies comparisons of the rDNA unit reveal a high degree of conservation in coding regions (18S, 5.8S, 25S and 5S genes) and considerable sequence differences in the internal transcribed spacer (ITS) and intergenic spacer (IGS) (Hijri et al., 1999) (Fig. 1). Eom et al. (2004) reported identification of AM fungi colonizing Panax ginseng in Korea using 18S rDNA Sequence. However there were some difficulties in AM fungi identification because of unselective amplification by primers and lack of accumulated sequencing data.

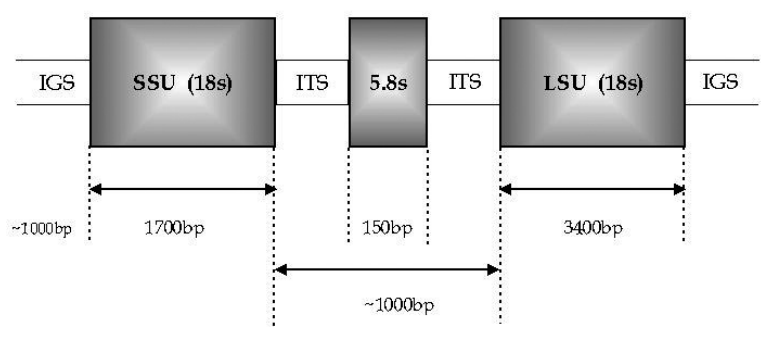

Fig. 1. Ribosomal DNA gene variability.

IGS; Intergenic spacer, ITS; Internal transcribed spacer, SSU; Small subunit, LSU; Large subunit.

In our preliminary study we found that native plant species in upland agroecosystem differed significantly in mycorrhizal species (Cho et al., 2006). Through both morphology-based and molecular biological approaches of the spores from various soils, total 9 species of 6 genera, such as 3 species of Glomus, 1 species of 
Paraglomus, Gigaspora, Acaulospora and Archaeospora, respectively and 2 species of Scutellospora were identified at Chungbuk province, and in Chungnam province, total 6 species of 5 genera, such as 2 species of Gigaspora, 1 species of Glomus, Scutellospora, Acaulospora and Archaeospora, respectively were confirmed.

This study was carried out to perform the identification of arbuscular mycorrhizal fungi colonized in Korean Ginseng roots. Those approaches include thorough investigation of morphological characteristics of spores harvested from Ginseng root associated soil and molecular biological identification of AM fungi in Ginseng roots. Firstly various mycorrhizal fungi from the Ginseng root-associated soil beds in Chungcheong-province are collected, and their identification was done by morphological features. In addition rDNA sequencing characteristics of AM fungi in different aged Ginseng roots in terms of the root age were evaluated by using designed specific primers.

\section{MATERIALS AND METHODS}

\section{Collection of root-associated soils and ginseng roots}

The ginseng root-associated soil samples from each individual plant were collected, each sample consisting of five bulked sub-samples $\left(200 \mathrm{~cm}^{3}\right.$ soil cores) randomly collected at 10 to $20 \mathrm{~cm}$ depth. Ginseng roots were collected in general crop fields in the Chungcheong province (Table 1), middle parts of Korea. For the mycorrhizal survey 8 individual Ginseng roots were randomly chosen at 5 sites in two provinces. Root samples for quantifying mycorrhizal colonization of different ages were collected and separated from the soil, washed and fixed in FAA (37\% formaldehyde-glacial acetic acid-95\% ethanol, 9:0.5:0.5, v/v/v).

Table 1. Collection sites of Ginseng roots

\begin{tabular}{clc}
\hline Sample ID & \multicolumn{1}{c}{ Collection sites } & Note \\
\hline G01 & Munwei, Cheongwon, Chungbuk & 1 yr root \\
G02 & Kwangam, Jungpyung, Chungbuk & 2 yr root \\
G03 & Buyeon, Cheongwon, Chungbuk & 3 yr root \\
G04 & Buyeon, Cheongwon, Chungbuk & $3 \mathrm{yr}$ root \\
G05 & Munduck, Cheongwon, Chungbuk & 4 yr root \\
G06 & Munduck, Cheongwon, Chungbuk & 4 yr root \\
G07 & Jungdo, Geumsan, Chungnam & 4 yr root \\
G08 & Jungdo, Geumsan, Chungnam & 5 yr root
\end{tabular}

\section{Isolations of spores from soils}

The AM fungal spores were extracted from the rhizosphere soils by wet sieving and decanting followed by sucrose gradient centrifugation (Daniels and Skipper, 1982; Sieverding, 1991). After centrifugation, the supernatant was poured through a $50 \mu \mathrm{m}$ mesh and quickly rinsed with tap water. Spores were grouped, under a dissecting microscope, according to their morphological characteristics and used to identify AM fungi and to initiate cultures of the different native AM fungal isolates.

\section{Morphological characterization of spores by microscopical observation}

After confirming under the light microscope the apparent purity of the cultures of the different AM morphotypes, spores were identified to genus and, when possible, to species level. Criteria for morphological spore characterization were mainly based on spore size and colour, wall structure and hyphal attachment (Walker, 1983; Morton and Benny, 1990; Schenk and Perez, 1990; Dodd and Rosendahl, 1996; INVAM, 1997). In order to assess the colonization, fine roots of host plant were stained with acid fuchsin (Kormaik and McGraw, 1982; Koske and Gemma, 1989). Colonization was determined by a grid intersect method (Giovannetti and Mosse, 1980) based on microscopical observation.

\section{Molecular characterization (DNA sequencing) Isolation of DNA}

Total genomic DNA of the different AM fungal morphotypes was isolated from approximately 50 to 60 spores, which were placed in microcentrifuge tubes containing $40 \mu \mathrm{l}$ milli Q-water and crushed with a miniature pestle. DNA extraction was done by DNeasy Plant Mini Kit (QIAGEN Science, USA) according to Technical Manual from QIAGEN (Gosselin et al., 1995; Wyss and Bonfante, 1993). The genomic DNA was repeatedly purified with the CTAB extracting buffer until a single band was obtained on gel. The total genomic DNA extracted above was amplified using the primers and conditions listed by Lee and Yoo (2000). The supernatant was frozen at $-20^{\circ} \mathrm{C}$ and used as template for PCR.

\section{Polymerase chain reaction}

Small subunit (SSU) rDNA gene sequences were PCR amplified from the purified total DNA by using the universal primer NS1-NS4 and the AM specific primer AML1-AML2 (Auh, 2004) (van Tuinen et al., 1998, Fig. 2). The latter primers were designed based on the small subunit of the nuclear ribosomal DNA (18S rDNA). The $1^{\text {st }}$ PCR mixture consisted of $1 \mu \mathrm{l}$ of universal primer NS1/NS4, $1 \mu \mathrm{l}$ of DNA extract, $7 \mu \mathrm{l}$ of nuclease free

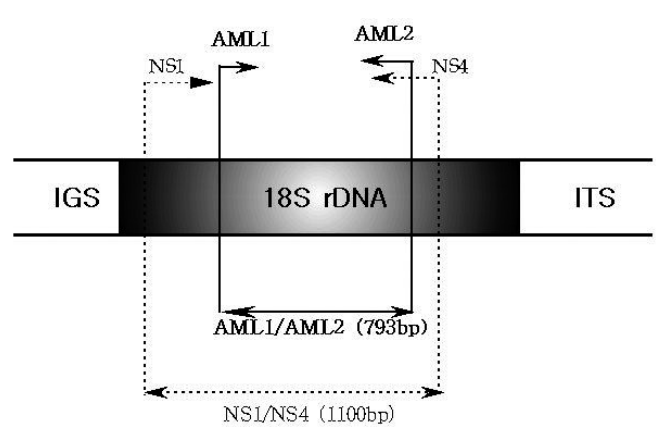

Fig. 2. 18S rDNA gene with annealing sites of primer pairs, NS1/NS4 and AML1/AML2 and their approximate DNA lengths (Lee, 2003). 
Table 2. Characteristics of primers used in this study and conditions of PCR (Lee, 2003)

\begin{tabular}{|c|c|c|c|}
\hline \multicolumn{3}{|c|}{ Primer } & \multirow{2}{*}{ PCR conditions } \\
\hline & Nucleotide sequences & $\mathrm{Tm}^{\mathrm{a}}$ & \\
\hline \multicolumn{4}{|c|}{ NS1/NS4 (30 cycles) } \\
\hline NS1 & 5'GTAGTCATATGCTTGTCTC-3' & & $\begin{array}{l}95^{\circ} \mathrm{C}(3 \mathrm{~min}), 40^{\circ} \mathrm{C}(1 \mathrm{~min}), 72^{\circ} \mathrm{C}(1 \mathrm{~min})-1 \mathrm{cycle} ; \\
95^{\circ} \mathrm{C}(30 \mathrm{sec}), 40^{\circ} \mathrm{C}(1 \mathrm{~min}), 72^{\circ} \mathrm{C}(1 \mathrm{~min}, 30 \mathrm{sec}), 40^{\circ} \mathrm{C}-28\end{array}$ \\
\hline NS4 & 5'-TTCCGTCAATTCCTTTAAG-3' & $48.3^{\circ} \mathrm{C} \mathrm{C}$ & $95^{\circ} \mathrm{C}(30 \mathrm{sec}), 40^{\circ} \mathrm{C}(1 \mathrm{~min}), 72^{\circ} \mathrm{C}(10 \mathrm{~min})-1$ cycle \\
\hline \multicolumn{4}{|c|}{ AML1/AML2 ( 30 cycles) } \\
\hline AML1 & 5'-AACTTTCGATGGTAGGATAGA-3' & $47.2^{\circ} \mathrm{C}$ & $95^{\circ} \mathrm{C}(3 \mathrm{~min}), 47^{\circ} \mathrm{C}(1 \mathrm{~min}), 72^{\circ} \mathrm{C}(1 \mathrm{~min})-1$ cycle; \\
\hline AML2 & 5'-CCAAACACTTTGGTTTCC-3' & $47.1^{\circ} \mathrm{C}$ & $\begin{array}{l}95^{\circ} \mathrm{C}(30 \mathrm{sec}), 47^{\circ} \mathrm{C}(1 \mathrm{~min}), 72^{\circ} \mathrm{C}(1 \mathrm{~min})-28 \text { cycles; } \\
95^{\circ} \mathrm{C}(30 \mathrm{sec}), 47^{\circ} \mathrm{C}(1 \mathrm{~min}), 72^{\circ} \mathrm{C}(10 \mathrm{~min})-1 \text { cycle }\end{array}$ \\
\hline
\end{tabular}

a) Melting temperature was determined using $50 \mathrm{mM}$ salts concentration

water, $10 \mu \mathrm{l}$ of the PCR master mix (500 unit/ml taq DNA polymerase, $250 \mu \mathrm{mM}$ dNTP, $1.5 \mathrm{mM} \mathrm{MgCl}_{2}, \mathrm{pH}$ 8.5; Promega Co., USA) in a $20 \mu \mathrm{l}$ reaction volume. PCR was performed in an automated thermal cycler (PTC-200 Peltier Thermal Cycler, MJ Research, INC. USA) and used to $2^{\text {nd }}$ PCR-DNA sample. The $2^{\text {nd }}$ PCR was done by using AM fungi specific primer AML1/AML2 (White et al., 1990; Lee, 2003). The PCR products were separated by electrophoresis in $1.0 \%$ agarose gels, stained with ethidium bromide, and visualized by UV trans-illumination. Table 2 represents characteristics of used primers and PCR condition.

\section{Cloning and sequencing}

PCR products were separated on an agarose gel, and the expected approximately 550-bp band was eluted by AccuPrep ${ }^{\mathrm{TM}}$ gel purification kit (Bioneer Co.). After purification, the sticky (-A) -ended PCR-product was cloned into the pGEM-T easy $\operatorname{Vector}^{\mathrm{TM}}$ (50 ng/ $\mu \ell$; Promega, USA) and transformed into Escherichia coli (JM109; using as the competent cell). The positive transformed cells were screened by X-gal (white colonies were selected only) and extracted to insert-DNA included plasmid using AccuPrep ${ }^{\mathrm{TM}}$ plasmid extraction kit (Bioneer Co.). These plasmids were screened using the (NS1/NS4) primer amplification.

The amplication of insert DNA in plasmid was done using SP6 (5'-TATTTAGGTGACACTATAG-3') and T7 (5'-TAATACGACT CATATAGGG-3'). DNA sequences were done by automatic sequencer ABIPRISM ${ }^{\mathrm{TM}}$ (Perkin-Elmer, USA at Eugenetech Co., Korea). Sequencing was analyzed by both ways of reverse and forward sequences, and then re-calculated with matching procedures of forward and reverse readings. Reverse sequences were reverse complemented and aligned with forward sequences by GENDOC program. All sequences were submitted to a BLAST search using the GenBank database (http://www.ncbi.nlm.nih.gov, Gehrig et al., 1996; Tae, 2000; Tae et al., 2002; Thompson et al., 1994; Saitou and Nei, 1987; Altschul et al., 1990).

\section{RESULTS AND DISCUSSION}

\section{Morphogical identification based on spores in gin- seng root-associated soil}

The arbuscular mycorrhizal (AM) fungi are currently all classified in the order Glomales (Morton, 1988). The term vesicular-arbuscular mycorrhiza (VAM) was originally applied to symbiotic association formed by all fungi in the Glomales, but because a major suborder lacks the ability to form vesicles in roots, AM is now the preferred acronym. The diagnostic feature of AM fungi is the development of a highly branched arbuscule within root cortical cells. The fungus initially grows between cortical cells, but soon penetrates the host cell wall and grows within the cell. As the fungus grows, the host cell membrane invaginates and envelops the fungus, creating a new compartment where material of high molecular complexity is deposited. The arbuscules are relatively short lived, less than 15 days, and are often difficult to see in field-collected samples. The order Glomales is further divided into families and genera according to the spore morphology.

Vegetative structures of AM fungi (i.e. mycorrhizae and mycelium in the soil) occur largely under ground, and are difficult to be tracked and identified. Identification of biological species in the AM fungi was mostly investigated based on the morphological and developmental characteristics of fungal spores (Morton and Benny, 1990). More than 150 AM fungi are described based on their spore morphology (Walker and Trappe, 1993), but spore morphotyping requires considerable experiences (Clapp et al., 2001), and spore counts may not reflect the in planta composition of AMF communities (Clapp et al., 1995; Merryweather and Fitter, 1998; Turnau et al., 2001), due to taxon-specific differences between sporulation and root colonization rates. Therefore, more adequate methods are needed to accurately identify the mycorrhizal fungi.

Morphology-based approach of the spores from ginseng root-associated soils was applied to characterize the AM fungi spores. This is the first step to analyze the diversity of AM fungi in the Ginseng fields of Chungcheong province, Korea. By following this 
approach, only five distinguishable spore morpho-types, three genera of AM fungi, were found. As shown in Fig. 3, five morphological species, Glomus mosseae, Glomus intraradices, Gigaspora margarita, Acaulospora longular and Gigaspora gigantea were recorded as spores in the soil samples. Among these, Glomus mosseae, Glomus intraradices and Acaulospora longular were the most commonly encountered species

Three genera of AM fungi were identified, among which Glomus and Acaulospora were dominant with frequencies of $55 \%$ and $25 \%$, respectively. The frequency of Gigaspora genera was low. Glomus mosseae has globose or irregular shape of spore, 80-240 $\mu \mathrm{m}$ in diameter, consisted to thin outer and thick inner walls, and funnel-type mycelia at spore base attached. Spores of Glomus intraradices were globose, obovate, to irregular in shape, 40-120 $\mu \mathrm{m}$ in diameter, hyaline to pale yellow in color. They are formed singly and freely in soil or in colonized roots. Gigaspora margarita Becker \& Hall has globose and obovate spores with 2 or 3 layers and $30 \mu \mathrm{m}$ in thickness, 240-350 $\mu \mathrm{m}$ in diameter, milky to pale yellow in color and strong dark purple by Melzer's reagent. Gigaspora gigantea has dark pinkish red in colored spores, globose or obovate shape with $10 \mu \mathrm{m}$ thin wall and $40 \mu \mathrm{m}$ bulb-shaped suspensor attached, and 200-350 $\mathrm{m}$ in diameter, pale yellow green in color and pale pinky colored by Melzer's reagent. Spores of Acaulospora longula have globose or obovate shape with 5 layers wall and 100-200 $\mu \mathrm{m}$ in diameter, milky to pale yellow in color and red colored inner wall by Melzer's reagent.
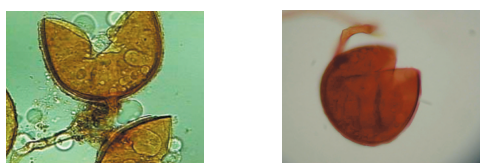

Glomus mosseae Glomus intraradices

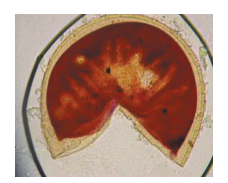

Acaulospora longular

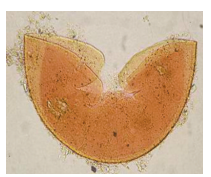

Gigaspora margarita

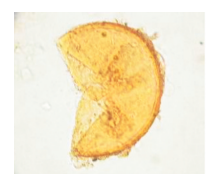

Gigaspora gigantea
Fig. 3. Identified spores in the Ginseng rhizosphere soils.

\section{AM fungi colonization}

$\mathrm{AM}$ fungi colonization in the Ginseng roots were observed by Microscope as in Fig. 4. Two and three year-old roots showed infected by AM fungi, particularly heavily infection in 3 year-old root of Buyeon, Cheongwon, Chungbuk. There were no typical vesicle and only abundant arbuscules in the cortex. Especially the colonization of 4 year old root showed very complicate distribution of AM fungi arbusucles. Typical vesicle (V) and arbuscule (A) were observed in the five year-old roots.

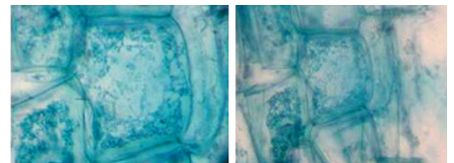

2 year $\square$ old

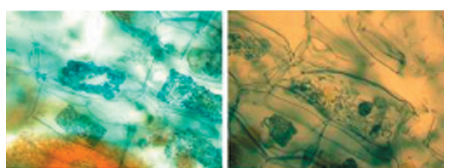

4 year $\square$ old

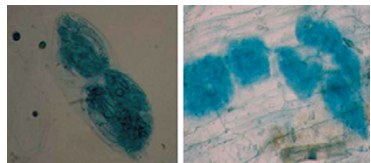

3 year $\square$ old

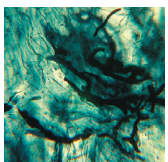

5 year $\square$ old
Fig. 4. Microscopic features of intracellular cells in the cortical layers of Ginseng roots. View of arbuscular hyphae (A, left) and vesicle ( $\mathrm{V}$, right) in hairy root of 5 year-old Ginseng. Sites: 2 year-old: Kwangam, Jungpyung, Chungbuk; 3 year-old: Buyeon, Cheongwon, Chungbuk; 4 year-old: Munduck, Cheongwon, Chungbuk; 5 year-old: Jungdo, Geumsan, Chungnam.

AM fungi colonization in the roots was measured by a grid intersect method (Giovannetti and Mosse, 1980). There was some increasing colonization tendency with the increase of culture periods. The colonization rates were progressed with the increase of cultivation period, relatively low infection rate in the two year-old root, heavily infected in the three year-old root, cube shape of intensive hyphal coil and distributed toward longitudinally in four year-old root, and eventually showed clear internal arbuscular hypae and vescicle.

\section{Molecular characterization (DNA sequencing)}

The molecular biological identification of AM fungi has been a complicated task in the past because of the considerable degree of variation detected among the copies of rDNA within single spores(Calvente et al., 2004). However, recent reports indicated that SSU rRNA sequence analysis is a suitable tool to inter-phylogenetic relationship among AM fungi since the expected sequence differences could be more easily linked to a taxonomic entity than the possibly multi-allelic ITS sequences (Schwarzott and Schüßler, 2001).

PCR primers were used to confirm AM fungi in Ginseng roots. Small subunit (SSU) rDNA gene sequences were PCR amplified from the purified total DNA by using the universal primer NS1-NS4 and the AM specific primer AML1-AML2 (Auh, 2004) (van Tuinen et al., 1998). Finally, 8 cloned DNA fragments were selected, and displayed in the agarose gel as shown in Fig. 5.

After purification, the sticky (-A) -ended PCR-product was cloned and transformed into $E$. coli. The positive transformed cells were extracted to insert-DNA included plasmid using AccuPrep ${ }^{\mathrm{TM}}$ plasmid extraction kit (Bioneer Co.). These plasmids were screened using the primer (NS1/NS4) amplification. The cloned DNA fragments were selected and re-amplified to the plasmids as shown in Fig. 6. Then, selected one clone from each group and purified plasmids were 


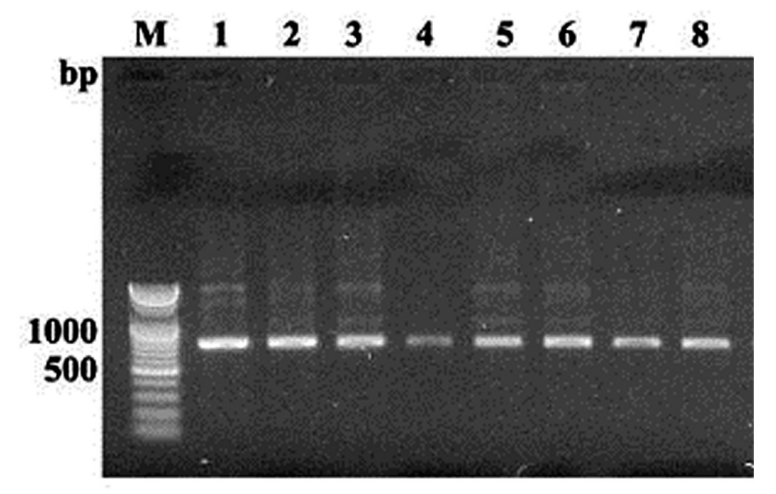

Fig. 5. PCR products of $18 \mathrm{~s}$ rDNA fragment of AM fungi in Ginseng roots. Lane M, molecular size marker (100-bp ladder), 1: G01 (1 yr-old), 2: G02 (2 yr-old), 3: G03 (3 yr-old), 4: G03 (3 yr-old), 5: G04 (4 yr-old), 6: G04 (4 yr-old), 7: G04 (4 yr-old), 8: G05(5 yr-old).

automatically sequenced on an ABIPRISM ${ }^{\mathrm{TM}} 377$ (Perkin-Elmer, USA). The standard primer SP6 and T7 were used for sequencing of insert-DNA regions (Helgason et al., 2002).

Based on the above collaborated molecular techniques, the AM fungi in the Ginseng roots were genetically characterized. As shown in Table 3, the accession number for the new sequences, as deposited in the EMBL database are as follows: 4 Glomus and 1 Acaulospora genera, Glomus sinuosum (AJ133706), Glomus fasciculatum (Y17640), Glomus intraradices (AY635831), Glomus mossae (AJ699064) and Acaulospora spp. (AY394664).

There was observed only one AM fungus, Glomus sinuosum, from one year-old Ginseng root, but two year-old root had three AM fungi, Glomus fasciculatum, Glomus intraradices and Glomus sinuosum. Three year-old root had two AM fungi, Glomus sinuosum and one new AM fungus, Acaulospora spp.

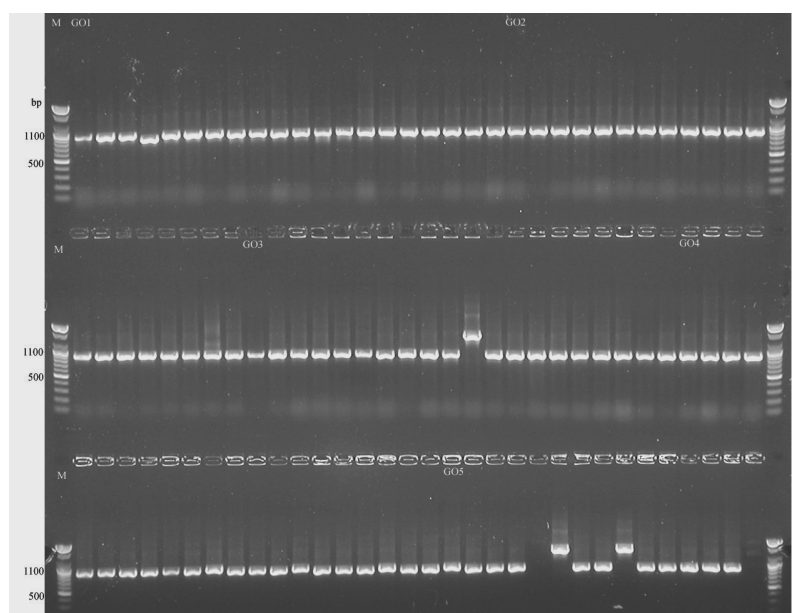

Fig. 6. The confirmation of the plasmid (pGEM-T Easy Vector ${ }^{\mathrm{TM}}$ ) inserted with the fragment of 18s rDNA's amplified with the specific primers. Lane M, molecular weight marker (100-bp ladder); Lanes were corresponded to the lanes of Fig. 5.

(AY394664). There were found three AM fungi in 5 year-old root, Glomus sinuosum, Glomus fasciculatum and Glomus intraradices. Comparisons of the obtained sequences with those present in the database revealed that they showed more than 95-99\% identity to the SSU rDNA gene of different AM fungal isolates.

The sequences of DNA band of AM fungi in Ginseng root were aligned with GENDOC program as shown in Fig. 7. After making the consensus sequences using GENDOC program, Tree View and CLUSTAL X (Thompson et al., 1994) was used for multiple alignment and neighbor-joining phylogenetic dendrogram (Saitou and Nei, 1987) as shown in Fig. 8 using rDNA sequences of AM fungi selected from Gene Bank of NCBI (Gehrig et al., 1996; Tae et al., 2002; Eom et al., 2004).

These identification results concerned to the AM fungi in Ginseng roots emphasize the importance of

Table 3. BLAST search on NCBI with analyzed sequences for Identification of AMF in Panax ginseng

\begin{tabular}{|c|c|c|c|c|}
\hline Years & Host Plant & Fungal Species & Accession no. & Identities \\
\hline 1 & P. ginseng & Glomus sinuosum & AJ133706 & $765 / 790(96 \%)$ \\
\hline 2 & P. ginseng & $\begin{array}{l}\text { Glomus fasciculatum } \\
\text { Glomus intraradices } \\
\text { Glomus sinuosum }\end{array}$ & $\begin{array}{c}\text { Y17640 } \\
\text { AY635831 } \\
\text { AJ133706 }\end{array}$ & $\begin{array}{l}789 / 792(99 \%) \\
789 / 792(99 \%) \\
767 / 790(97 \%)\end{array}$ \\
\hline 3 & P. ginseng & $\begin{array}{l}\text { Acaulospora spp. } \\
\text { Glomus sinuosum }\end{array}$ & $\begin{array}{l}\text { AY394664 } \\
\text { AJ133706 }\end{array}$ & $\begin{array}{l}782 / 789(99 \%) \\
770 / 790(97 \%)\end{array}$ \\
\hline 4 & P. ginseng & $\begin{array}{l}\text { Glomus sinuosum } \\
\text { Acaulospora spp. } \\
\text { Glomus mossae }\end{array}$ & $\begin{array}{l}\text { AJ133706 } \\
\text { AY394664 } \\
\text { AJ699064 }\end{array}$ & $\begin{array}{l}769 / 791(97 \%) \\
782 / 795(98 \%) \\
699 / 727(96 \%)\end{array}$ \\
\hline 5 & P. ginseng & $\begin{array}{l}\text { Glomus sinuosum } \\
\text { Glomus fasciculatum } \\
\text { Glomus intraradices }\end{array}$ & $\begin{array}{l}\text { AJ133706 } \\
\text { Y17640 } \\
\text { AY635831 }\end{array}$ & $\begin{array}{l}766 / 789(97 \%) \\
790 / 792(99 \%) \\
684 / 714(95 \%)\end{array}$ \\
\hline
\end{tabular}




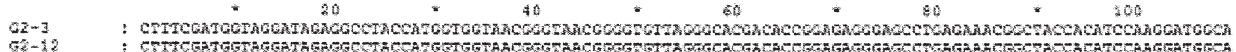
$\sigma^{2}-120$

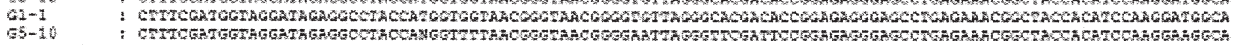

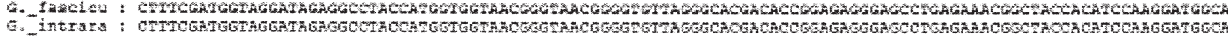

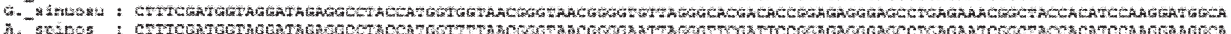

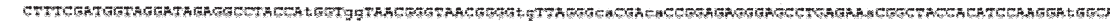

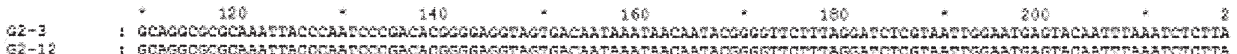
as-10

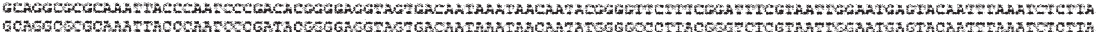

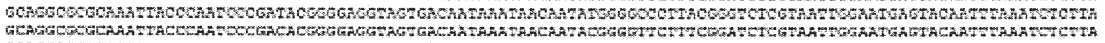

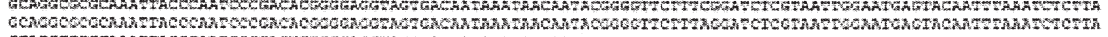

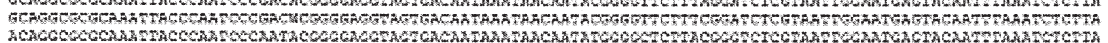

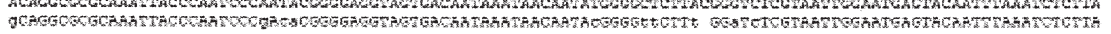

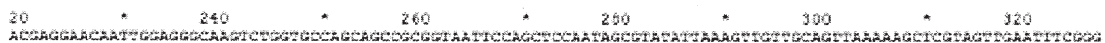

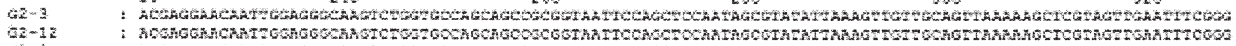

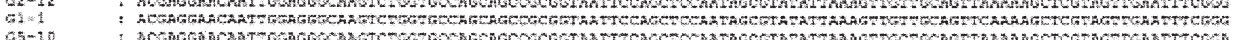

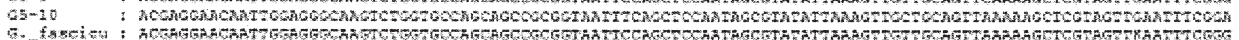

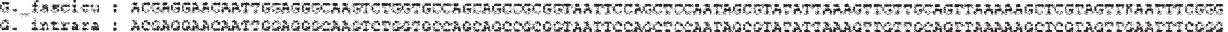

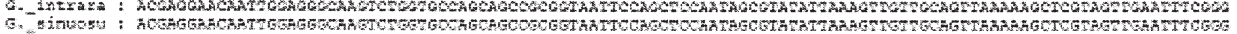

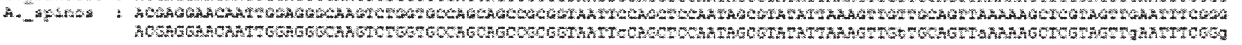

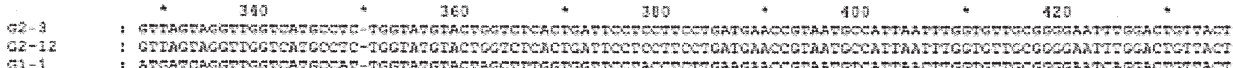

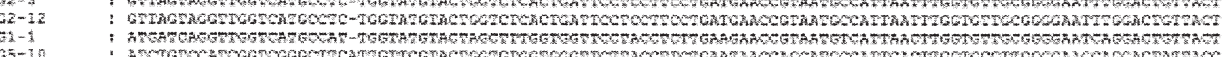

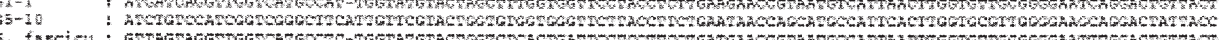

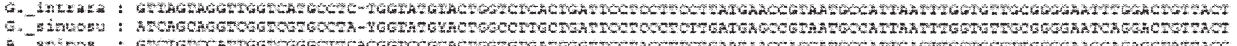

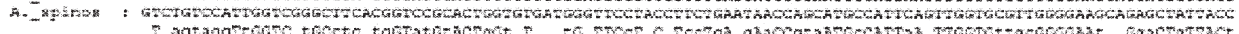

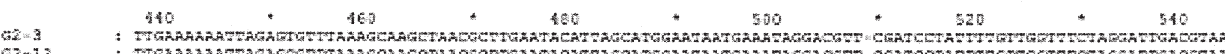

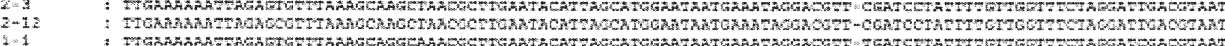

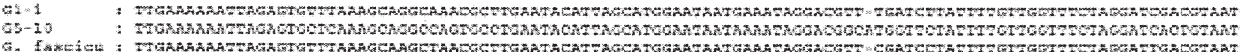

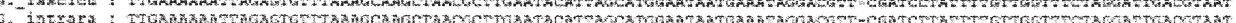
Q.

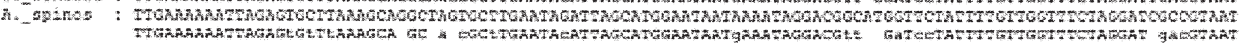

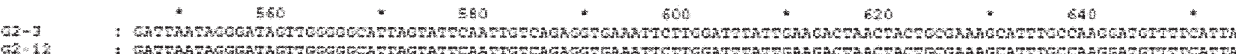

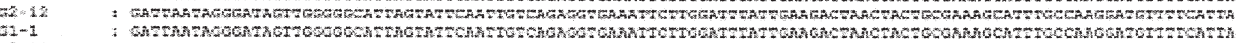
Ga 12 :

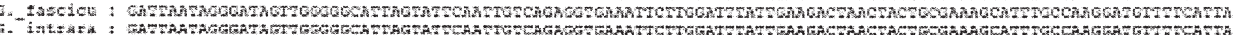

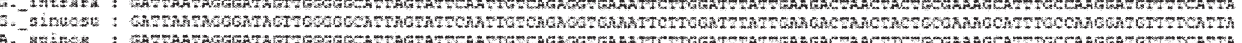

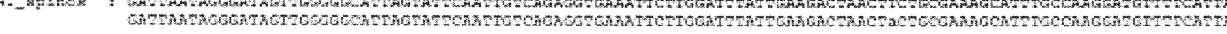

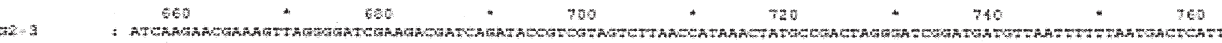

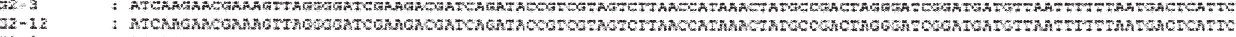

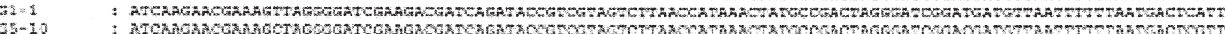
a. faweice : ATC

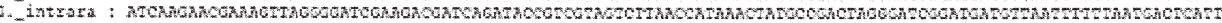

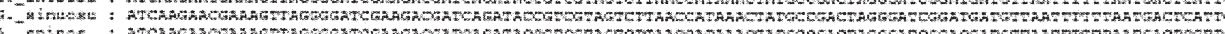

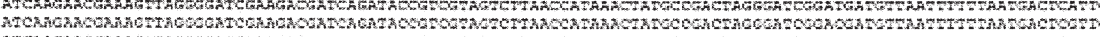
(5) tho

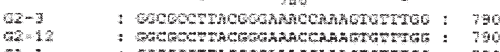

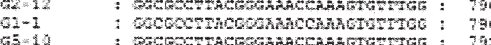

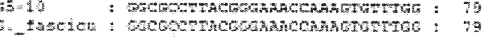

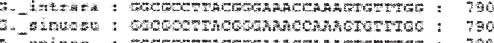

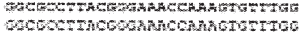

Fig. 7. Sequence alignment of PCR products amplified with AM fungi specific primers.

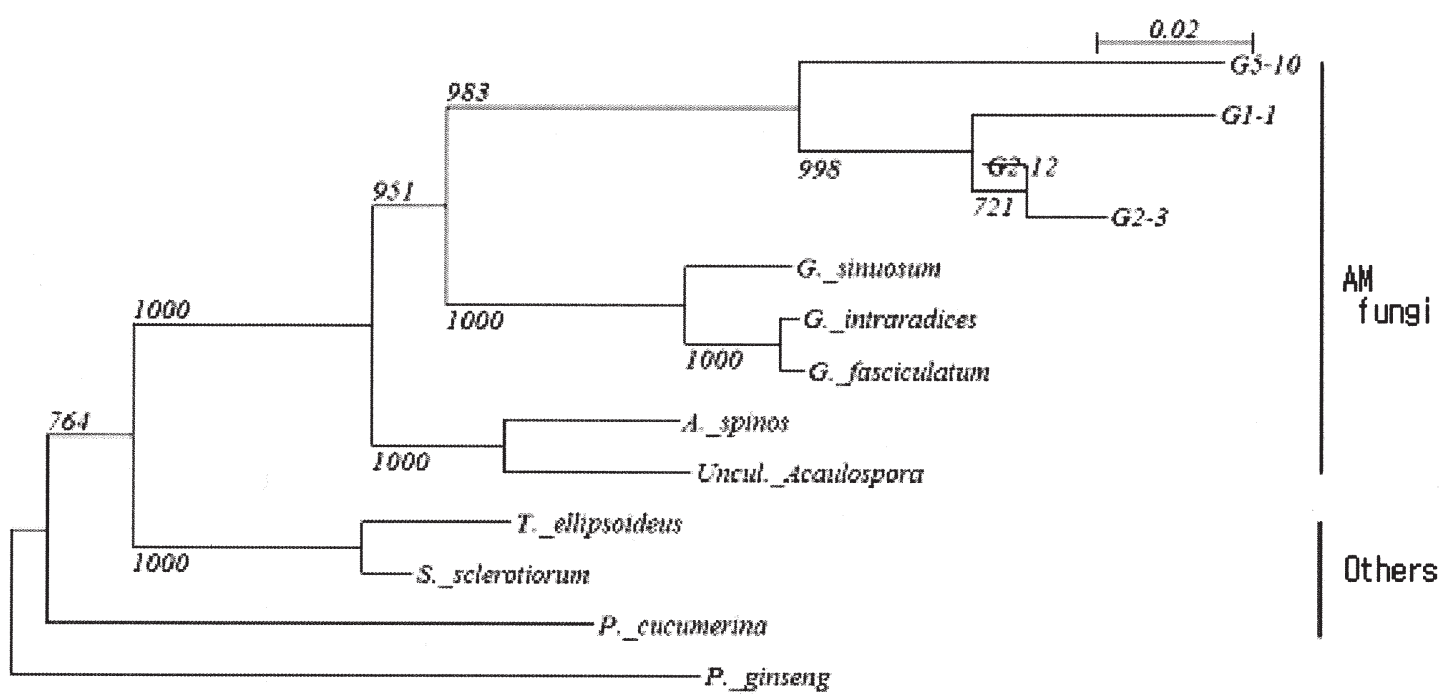

Fig. 8. Neighbour-joining phylogenetic relationship among AM fungi colonizing in Ginseng root based on 18s rDNA sequences. 
exploiting the natural diversity of AM fungi not only in Ginseng root-associated soils but also in Ginseng roots, particulary in Chungcheong province, Korea, and would be a starting point to formulate particular AM fungi inoculants to be applied for the Ginseng production with optimized quality.

\section{CONCLUSIONS}

This study was carried out to perform the collection of AM fungi in soils and roots from various Ginseng cultivation sites of Chungcheong province in Korea and to identify the AM fungi which are associated to symbiotic relation with Ginseng. Those approaches include thorough investigation of morphological characteristics and molecular biological techniques.

Based on morphology-based approach of the spores from ginseng root-associated soils, five distinguishable spore morpho-types, three genera of AM fungi, were found; Glomus mosseae, Glomus intraradices, Gigaspora margarita, Acaulospora longular and Gigaspora gigantea. Among these, Glomus mosseae, Glomus intraradices and Acaulospora longular were the most commonly encountered species. Glomus and Acaulospora were dominant with frequencies of $55 \%$ and $25 \%$, respectively. The frequency of Gigaspora genera was low.

Two and three year-old roots showed infected by AM fungi, particularly heavily infection in 3 year-old root. The colonization of 4 year old root showed very complicate distribution of AM fungi arbusucles. Typical vesicle (V) and arbuscule (A) were observed in the five year-old roots. AM fungi colonization rates were progressed with the increase of cultivation period, relatively low infection rate in the two year-old root, heavily infected in the three year-old root, cube shape of intensive hyphal coil and distributed toward longitudinally in four year-old root, and eventually showed clear internal arbuscular hypae and vescicle.

By sequence analysis of the small subunit of the nuclear ribosomal DNA (18S rDNA), the AM fungi in the Ginseng roots were identified as follows; 4 Glomus and 1 Acaulospora genera, Glomus sinuosum (AJ133706), Glomus fasciculatum (Y17640), Glomus intraradices (AY635831), Glomus mossae (AJ699064) and Acaulospora spp. (AY394664). There was observed only one AM fungus, Glomus sinuosum, from one year-old Ginseng root, but two year-old root had three AM fungi, Glomus fasciculatum, Glomus intraradices and Glomus sinuosum. Three year-old root had two AM fungi, Glomus sinuosum and one new AM fungus, Acaulospora spp. (AY394664). There were found three AM fungi in 5 year-old root, Glomus sinuosum, Glomus fasciculatum and Glomus intraradices. These identification results concerned to the AM fungi in Ginseng roots would be a starting point to formulate particular AM fungi inoculants to be applied for the Ginseng cultivation with optimized quality.

\section{ACKNOWLEDGEMENT}

This study was carried out mainly with the Grants of the Bioindustry Research Projects, Chungbuk Province (2004-2007).

\section{REFERENCES}

Abdalla, M. E. and G. M. Abdel-Fattah 2000 Influence of the endomycorrhizal fungus Glomus mosseae on the development of peanut pod rot disease in Egypt. Mycorrhiza, 10: 29-35

Altschul, S. F., T. L. Madden, A. A. Schäffer, J. Zhang, Z. Zhang, W. Miller and D. J. Lipman 1997 Gapped BLAST and PSI-BLAST: A new generation of protein database search programs. Nucleic Acids Research, 25: 3389-3402

Armstrong, L. and R. L. Peterson 2002 The interface between the arbuscular mycorrhizal fungus, Glomus intraradices and root cells of Panax quinquefolius; A Paris-type mycorrhizal association. Mycologia, 94: 587-595

Auh J. K. 2004 Identification of arbuscular mycorrhizal fungi in Korean ginseng (Panax ginseng) by $18 \mathrm{~S}$ rDNA sequencing. MS Dissertation, Korea National University of Education, Cheongweon, Korea

Bever, J. D., J. B. Morton, J. Antonovics and P. A. Schultz 1996 Host dependent sporulation and species diversity of arbuscular mycorrhizal fungi in a mown grassland, J. Ecol., 84: $71-82$

Bolan, N. S. 1991 A critical review of the role of mycorrhizal fungi in the uptake of phosphorus by plants, Plant Soil, 134: 189-208

Boscot, F., J. C. Munch, J. Y. Charosset and M. Gardes 2000 Recent advandes in exploring physiology and biodiversity of ectomycorrhizas highlight the functioning of these symbioses in ecosystems. Microbiology Reviews, 24: 606-607

Burrows, R. L. and F. L. Pfleger 2002a Arbuscular mycorrhizal fungi respond to increasing plant diversity, Can. J. Bot., 80: $120-130$

Burrows, R. L. and F. L. Pfleger 2002b Host responses to AMF from plots differing in plant diversity, Plant Soil, 240: $169-179$

Calvente, R., C. Cano, N. Ferrol, C. Azcon-Aguilar and J. M. Barea 2004 Analysing natural diversity of arbuscular mycorrhizal fungi in olive tree plantations and assessment of the effectiveness of native fungal isolates as inoculants for commercial cultivars of olive plantlets. Appl. Soil Ecology, 26: $11-19$

Cho N. S., D. -H. Kim, A. -H. Eom, J. W. Lee, T. H. Choi, H. -Y. Cho, A. Leonowicz and S. Ohga 2006 Identification of symbiotic arbuscular mycorrhizal fungi in Korea by morphological and DNA sequencing features of their spores. J. Fac. Agr. Kyushu Univ., 52(2): 201-210

Clapp, J. P., A. Rodriguez and J. C. Dodd 2001 Inter- and intra-isolate rRNA large subunit variation in Glomus coronatum spores. New Phytol., 149: 539-554

Clapp, J. P., A. Rodriguez and J. C. Dodd 2002 Glomales rRNA diversity-all that glistens is not necessarily glomalean? Mycorrhiza, 12: 269-270

Clapp, J. P., J. P. W. Young, J. W. Merryweather and A. H. Fitter 1995 Diversity of fungal symbionts in arbuscular mycorrhizas from a natural community. New Phytol., 130: 259-265

Daniels, B. A. and H. D. Skipper 1982 Methods for the recovery and quantitative estimation of propagules from soil. In Methods and Principles of Mycorrhizal Research (N.C. Schenck ed.), Americal Phytopathological Society press, St. paul, MN. USA. pp. 29-35

Darmono, T. W., M. L. Owen and J. L. Park 1991 Isolation and pathogenicity of Phytophthora cactorum from forest and ginseng garden soils in Wisconsin. Plant Disease, 75: 610-612 
Davies, F. T., J. R. Porter and R. G. Linderman 1993 Drought resistance of mycorrhizal pepper plants: independent of leaf phosphorus concentration, response in gas exchange, and water relations, Physiol. Plant., 87: 45-53

Dodd, J. C. and S. Rosendahl 1996 The BEG Expert System-a multimedia identification system for arbuscular mycorrhizal fungi. Mycorrhiza, 6: 275-278

Douds, D. D., G. Nagahashi and G. D. Abney 1996 The differential effects of cell wall-associated phenolics, cell walls, and cytosolic phenolics of host and non-host roots on the growth of two species of AM fungi, New Phytol., 133: 289-294

Eom, A. H., D. C. Hartnett and G. W. T. Wilson 2000 Host plant effects on arbuscular mycorrhizal fungal communities in tallgrass prairie, Oecologia, 122: 435-444

Eom, A. H., S. S. Lee, T. K. Ahn and M. W. Lee 1994 Ecological roles of arbuscular mycorrhizal fungi in two wild legume plants. Mycoscience, $\mathbf{3 5}$ : 69-78

Eom, A. H., J. K. Eo, D. H. Kim and H. S. Jeong 2004 Identification of arbuscular mycorrhizal fungi colonizing Panax ginseng using 18S rDNA Sequence. J. Korean Soc. Appl. Biol. Chem., 47(2): 182-186

Gardes, M., T. J. White, J. A. Fortin, T. D. Bruns and J. W. Taylor 1991 Identification of indigenous and introduced symbiotic in ectomycorrhizae by amplification of the nuclear and mitochondrial ribosomal DNA. Can. J. Bot., 69: 180-190

Gehrig, H., A. Schussler and M. Kluge 1996 Geosiphon pyriforme, a fungus forming endocytobiosis with Nostoc (Cyanobacteria), is an ancestral member of the Glomales: Evidence by SSU rRNA analysis. J. Mol. Evol., 43: 71-81

Giovannetti, M. and B. Mosse 1980 An evaluation of techniques for measuring vesicular arbuscular mycorrhizal infection in roots. The New Phytologist, 84: 489-500

Gosselin, L., R. Jobidon and L. Bernier 1995 Assessment of genetic variation within Chondrostereum purpureum from Quebec by random amplified polymorphic DNA analysis. Mycol. Res. 99: 151-158

Han, K. D., S. S. Lee, S. H. Ki m and M. W. Lee. 1996 Effect of beneficial microorganisms and mycorrhizal fungus colonized rhizoplane on the suppression of root rot pathogen, Fusarium solani. Korean J. Mycology, 24; 38-48

Hector, A., B. Schmid, C. Beierkuhrlein and M. C. Caldeira 1999 Plant diversity and productivity experiments in European grasslands, Science, 286: 1123-1127

Helgason, T., A. H. Fitter and J. P. W. Young 1999 Molecular diversity of arbuscular mycorrhizal fungi colonising Hyacinthoides nonscripta (bluebell) in a seminatural woodland. Mol. Ecol., 8: 659-666

Helgason, T., J. W. Merryweather, J. Denison, P. Wilson, J. P. W. Young and A. H. Fitter 2002 Selectivity and functional diversity in arbuscular mycorrhizas of co-occurring fungi and plants from a temperate deciduous woodland. J. Ecol., $\mathbf{9 0}$ : 371-384

Helgason, T., T. J. Daniell, R. Husband, A. H. Fitter and J. P. W. Young 1998 Ploughing up the wood-wide web? Nature, 394; 431

Henrion, B., F. Le Tacon and F. Martin 1992 Rapid identification of genetic variation of ectomycorrhizal fungi by amplification of ribosomal RNA genes. New Phytol., 122; 289-298

Hijri, M., M. Hosny, D. van Tuinen and H. Dulieu 1999 Intraspecific ITS polymorphism in Scutellospora castanea (Glomales, Zygomycota) is structured within multinucleate spores. Fungal Genet. Biol., 26: 141-151

INVAM 1997, http://www.invam.caf.wvu.edu/

Jakobsen, I., C. Gazey and L. K. Abbott 2001 Phosphate transport by communities of arbuscular mycorrhizal fungi in intact soil cores, New Phytol., 149: 95-103

Johnson, D., P. J. Vandenkoornhuyse, J. R. Leake, L. Gilbert, R. E. Booth, J. P. Grime, J. W. Young and D. J. Read 2004 Plant communities affect arbuscular mycorrhizal fungal diversity and community composition in grassland microcosms, New Phytol., 161: 503-515

Kaya, C., D. Higgs, H. Kirnak and I. Tas 2003 Mycorrhizal colonization improves fruit yield and water use efficiency in watermelon (Citrullus lanatus Thunb.) grown under well-watered and water-stressed conditions, Plant Soil, 253: 287-292

Klironomos, J. N., J. McCune, M. Hart and J. Neville 2000 The influence of arbuscular mycorrhizae on the relationship between plant diversity and productivity, Ecol. Lett., 3: $137-142$

Kormaik, P. P. and A. C. McGraw 1982 Quantification of vesicular-arbuscular mycorrhizae in plant roots. In: Schenck, N. C. (Ed.), Methods and Principles of Mycorrhizal Research. The American Phytopathological Society, St. Paul, USA, pp. $37-45$

Koske, R. E. and J. N. Gemma 1989 A modified procedure for staining roots to detect VA mycorrhizas. Mycological Research, 92: 486-505

Kuhn G., M. Hijiri and I. R. Sanders 2001 Evidence for the evolution of multiple genomes in arbuscular mycorrhizal fungi. Nature, 414: 745-748

Lanfranco, L., S. Perotto and P. Bonfante 1998 Applications of PCR for studying the biodiversity of mycorrhizal fungi. In: Applications of PCR in Mycology (Eds. Bridge, P. D., Arora, D. K., Reddy, C. A. and Elander, R. P.), CAB International, UK. pp. 107-124

Lee, J. K. 2003 Molecular biological identification of arbuscular mycorrhizal fungi collected from plant roots. MS Dissertation, Korea National University of Education, Cheongweon, Korea

Lee, K. J., H. Park and I. S. Lee 2004 Morphology of arbuscular mycorrhizal roots and effects of root age and soil texture on the mycorrhizal infection in Panax ginseng C. A. Meyer. $J$. Ginseng Res., 28(3): 149-156

Lee, S. S. and J. Y. Yoo 2000 Identification of the orchid mycorrhizal fungi isolated from the roots of Korean native orchid. Mycobiol., 25: 17-26

Li, T. S. C. 1994 Evaluation of chemical and non-chemical treatments for the control of ginseng replants disease. Acta Horticulture, 363: 141-146

Lovelock, C. E., K. Andersen and J. B. Morton 2003 Arbuscular mycorrhizal communities in tropical forests are affected by host tree species and environment, Oecologia, 135: 268-297

Lugo, M. A. and M. N. Cabello 2002 Native arbuscular mycorrhizal fungi (AMF) from mountain grassland (Cordoba, Argentinia) I. Seasonal variation of fungal spore density. Mycologia, 94: 579-586

McGonigle, T. P., J. P. Hovius and R. L. Peterson 1999 Vesicular arbuscular mycorrhizae of American ginseng (Panax quinquefolius) in cultivated field plots; Plant age affects the development of a colonization lag phase. Can. J. Bot., 77: 1028-1034

Merryweather, J. and A. Fitter 1998 The arbuscular mycorrhizal fungi of Hyacinthoides non-scripta. I. Diversity of fungal taxa. New Phytologist, 138: 117-129

Michel-Rosales, A. and M. Valdés 1996 Arbuscular mycorrhizal colonization of lime in different agroecosystems of the dry tropics. Mycorrhiza, 6: 105-109

Molina, R. 1997 Special Forest Products: Integrating Social Economic, and Bioogical Considerations into Ecosystem Management. In Creating A Forestry for The 21st Century. The Science of Ecosystem Management. Edited by K. A. Kohm and J. F. Franklin. Island Press. Washington, D. C. pp. 315-336

Morton, J. B. 1988 Taxonomy of VA mycorrhizal fungi: classification, nomenclature and identification. Mycotaxon, 32: $267-324$

Morton, J. B. and G. L. Benny 1990 Revised classification of arbuscular mycorrhizal fungi (Zygomycetes): A new order, Glomales, two new suborders, Glomineae and Gigasporineae, and two new families, Acaulosporaceae and Gigasporaceae, with an emendation of Glomaceae. Mycotaxon, 37: 471-492

Mullis, K. B. and F. A. Faloona 1987 Specific synthesis of DNA in vitro via a polymerase-catalyzed chain reaction. Methods in Enzymology, 155: 335-350 
Newsham, K. K., A. H. Fitter and A. R. Watkinson 1995 Arbuscular mycorrhizal protect an annual grass from root pathogenic fungi in the field, J. Ecol., 83, 991-1000

O'Connor, P. J., S. E. Smith and E. A. Smith 2002 Arbuscular mycorrhizas influence plant diversity and community structure in a semiarid herbland, New Phytol., 154: 209-218

Oh, S. H., H. Park, Y. H. Ryu and S. K. Mok 1978. Color Atlas of Ginseng Diseases and Insects. Kor. Ginseng Res. Inst., Monopoly Office pp. 26-30

Park, H., M. G. Lee, C. H. Lee and K. J. Lee 1990 Identification of VA mycorrhiza in the cultures Panax ginseng. Korean Soc. Soil Sci. Fert., 23: 73-76

Peterson, R. L. and M. L. Farquhar 1994 Mycorrhizas-Intergrated development between roots and fungi. Mycologia, 86: 311-326

Porter, W. M., A. D. Robson and L. K. Abbott 1987 Field survey of the distribution of vesicular-arbuscular mycorrhizal fungi in relation to soil pH. J. Applied Ecology, 24: 659-662

Ruiz-Lozano, J. M., C. Collados, J. M. Barea and R. Azcon 2001 Arbuscular mycorrhizal symbiosis can alleviate drought-induced nodule senescence in soybean plants, New Phytol, 151: 493-502

Saitou, N. and Nei, M. 1987. The Neighbor-joining method: a new method for reconsructing phylogenetic tree. Mol. Biol. Evol., 4: 406-425

Sander, I. R., M. Alt, K. Groppe, T. Boller and A. Wiemken 1995 Identification of ribosomal DNA polymorphisms among and within spores of the Glomales-application to studies on the genetic diversity of arbuscular mycorrhizal fungal communities. New Phytologist, 130: 419-427

Schenk, N. C. and Y. Perez 1990 Manual for Identification of VA Mycorrhizal Fungi. Synergistic Publications, Gainesville, Florida, p. 250

Schwarzott, D. and A. Schüßler 2001 A simple and reliable method for SSU rRNA gene DNA extraction, amplification and cloning from single AM fungal spores. Mycorrhiza, 10: 203-207

Shin, H. S., H. H. Lee and M. W. Lee 1986 Studies on the distribution of fungal and Fusarium - spp. Propagules in ginseng field soil. Korean J. Mycology, 14: 109-119

Sieverding, E. 1991 Vesicular-arbuscular mycorrhiza management in tropical agrosystems. Deutsche GTZ. GmbH Eschborn, p. 371

Simon, L., M. Lalonde and T. D. Bruns 1992 Specific amplification of $18 \mathrm{~S}$ fungal ribosomal genes from VA endomycorrhizal fungi colonising roots. Appl. Environ. Microbiol., 58: 291-295

Smith, M. D., D. C. Hartnett and G. W. T. Wilson 1999 Interacting influence of mycorrhizal symbiosis and competition on plant diversity in tallgrass prairie, Oecologia, 124: 574-582

Smith, S. E. and D. J. Read 1997 Mycorrhizal Symbiosis (2nd ed.), Academic Press, California. pp. 11-32

Smith, S. E. and D. J. Read 1997 Mycorrhizal Symbiosis. Academic Press, London, p. 605

Tae M. S. 2000 Molecular and morphological diversity of arbuscular mycorrhizal fungi collected at Mt. Wolak. MS Dissertation, Korea National University of Education, Cheongweon, Korea

Tae, M. S., A. H. Eom and S. S. Lee 2002 Sequence analyses of PCR amplified partial SSU of Ribosomal DNA for Identifying Arbuscular Mycorrhizsa Fungi in Plant roots. Mycobiol., 30: $13-17$

Thingstrup, I., H. Kahiluoto and I. Jakoben 2000 Phosphate transport by hyphae of field communities of arbuscular mycorrhizal fungi at two levels of P fertilization, Plant Soil, 221: 181-187

Thompson, J. D., D. G. Higgins and T. J. Gibson 1994 CLUSTAL
W: improving the sensitivity of progressive multiple sequence alignment through sequence weighting, position-specific gap penalties and weight matrix choice. Nucl. Acids Res., 22 4673-4680

Tilman, D., D. Wedin and J. Knopps 1996 Productivity and sustainability influenced by biodiversity in grassland ecosystems, Nature, 379: 718-720

Turnau, K., P. Ryszka, V. Gianinazzi-Pearson and D. van Tuinen 2001 Identification of arbuscular mycorrhizal fungi in soils and roots of plants colonizing zinc wastes in southern Poland. Mycorrhiza, 10: 169-174

Urcelay C. and S. Diaz 2003 The mycorrhizal dependence of subordinates determines the effect of arbuscular mycorrhizal fungi on plant diversity, Ecol. Lett., 6: 388-391

van der Heijden M. G. A., J. N. Klironomos, M. Ursic, P. Moutoglis, R. Streitwolf-Engel, T. Boller, A. Wiemken and I. R. Sanders 1998a Mycorrhizal fungal diversity determines plant biodiversity, ecosystem variability and productivity, Nature, 396: $69-72$

van der Heijden M. G. A., T. Boller, A. Wiemken and I. R. Sanders 1998b Different arbuscular mycorrhizal fungal species are potential determinants of plant community structure, Ecology, 79: 2082-2091

van der Heijden, M. G. A., A. Wiemken and I. R. Sanders 2003 Different arbuscular mycorrhizal fungi alter coexistence and resource distribution between co-occurring plant, New Phytol., 157: 569-578

van Tuinen, D., E. Jacquot, B. Zhao, A. Gollotte and P. V. Gianinazzi 1998 Characterization of root colonization profiles by a microcosm community of arbuscular mycorrhizal fungi using $25 \mathrm{~S}$ rDNA-targeted nested PCR. Molecular Ecology, 7: 879-887

Vandenkoornhuyse, P., R. Husband, T. J. Daniell, I. J. Watson, J. M. Duck, A. H. Fitter and J. P. W. Young 2002 Arbuscular mycorrhizal community composition associated with two plant species in a grassland ecosystem. Mol. Ecol., 11: 1555-1564

Vierheilig H., B. Bago, C. Albrecht, M. J. Poulin and Y. Piche 1998 Flavonoids and arbuscular-mycorrhizal fungi. Flavonoids in the Living System, 439: 9-33

Vierheilig H., R. Bennett, G. Kiddle, M. Kaldorf and J. Ludwig-Muller 2000 Differences in glucosinolate patterns and arbuscular mycorrhizal status of glucosinolate-containing plant species. New Phytologist, 146(2): 343-352

Walker, C. 1983 Taxonomic concepts in the Endogonaceae: spore wall characteristics in species descriptions. Mycotaxon, 18: $443-455$

Walker, C. and J. M. Trappe 1993 Names and epithets in the Glomales and Endogonales. Mycol. Res., 97: 339-344

Whitbread, F., T. P. McGonigle and R. L. Peterson 1996 Vesicular arbuscular mycorrhizal associations of American ginseng (Panax quinquefolius) in commercial production. Can. J. Bot., 74: 1104-1112

White, T. J., T. D. Bruns, S. Lee and J. Taylor 1990 Amplification and direct sequencing of fungal ribosomal RNA genes for phylogenetics. In: PCR Protocols: a Guide to Methods and Applications. Innis M. A., D. H. Gelfand, J. J. Sninsky and T. J. White (eds.), Academic Press, New York. pp. 315-322

Woo, S. Y., D. S. Lee and J. K. Min 2002 A study on the growth and environments of Panax ginseng in the different forest stands. J. Korean For. Soc., 91: 295-304

Wyss, S. and P. Bonfante 1993 Amplification of genomic DNA of arbuscular mycorrhizal (AM) fungi by PCR using short arbitrary primers. Mycol. Res., 97: 1351-1357

Yu, S. H., S. Nishimura and T. Hirosawa 1984 Morphology and pathogenicity of Alternaria panax from Panax ginseng in Japan and Korea. Annals Phytopathol. Soc. Japan, 50: 313-321 